\title{
Detecting Variation Trends of Temperature and Precipitation for the Dadu River Basin, China
}

\author{
Ying Wu, ${ }^{1,2}$ Wensheng Wang, ${ }^{1,2}$ and Guoqing Wang ${ }^{3}$ \\ ${ }^{1}$ College of Water Resource and Hydropower, Sichuan University, Chengdu 610065, China \\ ${ }^{2}$ State Key Laboratory of Hydraulics and Mountain River Engineering, Sichuan University, Chengdu 610065, China \\ ${ }^{3}$ State Key Laboratory of Hydrology-Water Resources and Hydraulic Engineering, Nanjing Hydraulic Research Institute, \\ Nanjing 210029, China \\ Correspondence should be addressed to Ying Wu; wuying.scm@163.com
}

Received 29 February 2016; Revised 19 May 2016; Accepted 22 May 2016

Academic Editor: Hiroyuki Hashiguchi

Copyright (๑) 2016 Ying Wu et al. This is an open access article distributed under the Creative Commons Attribution License, which permits unrestricted use, distribution, and reproduction in any medium, provided the original work is properly cited.

\begin{abstract}
This study analyzes the variation trends of temperature and precipitation in the Dadu River Basin of China based on observed records from fourteen meteorological stations. The magnitude of trends was estimated using Sen's linear method while its statistical significance was evaluated using Mann-Kendall's test. The results of analysis depict increase change from northwest to southeast of annual temperature and precipitation in space. In temporal scale, the annual temperature showed significant increase trend and the annual precipitation showed increase trend. For extreme indices, the trends for temperature are more consistent in the region compared to precipitation. This paper has practical meanings for an effective management of climate risk and provides a foundation for further study of hydrological situation in this river basin.
\end{abstract}

\section{Introduction}

In recent years, a great deal of research was focused on understanding climate change [1-4]. The effect of climate on hydrological cycle has recently been considered as a hot topic [5-9]. And the general consensus is that warming of the earth is very likely to enhance the hydrological cycle; this will cause changes in rainfall amount, frequency, intensity, and duration [10].

The global average surface temperature (the average of near surface air temperature over land and sea surface temperature) has increased since 1861 . Over the 20th century, the increase of global average surface temperature has been $0.6 \pm 0.2^{\circ} \mathrm{C}[11]$. Mean annual surface air temperature in Mainland China as a whole increased by about $1.1^{\circ} \mathrm{C}$ for the last 50 years, with a warming rate of about $0.22^{\circ} \mathrm{C} /$ decade [12]. Han et al. [13] analyzed the characteristics of temperature changes in the different regions in China and indicated that the trend of temperature change is overall upward, with a remarkable rate of $0.3^{\circ} \mathrm{C} /$ decade in northeast and a rate of $0.13^{\circ} \mathrm{C} /$ decade in South China.
Over the past 50 years, the annual precipitation in China as a whole showed no obvious trend [14-16]. However, on regional scale, there was a decreasing trend in the Yellow River Basin [17] and increasing trend in the middle and lower Yangtze River Basin [18]. Cheng [19] simply discussed the annual precipitation in Dadu River and showed an increasing trend, but the trend was not obvious.

It is now widely recognized that extreme events are very likely to increase as a result of climate change and have much greater impact on natural and human systems than a small shift in the mean values [20]. Zhai et al. [14] analyzed the changes in China's temperature and precipitation extremes and detected that mean minimum temperature has increased significantly in China during the past 40 years and normal rain days in China has a statistically significant reduction. Wang and Zhou [21] observed the trends of extreme precipitation events in China and showed that the extreme daily precipitation events increase significantly in southwest, northwest, and east China and decrease significantly in central, north, and northeast China. Zhang et al. [22] reported that temperature extreme indices are significant increases 


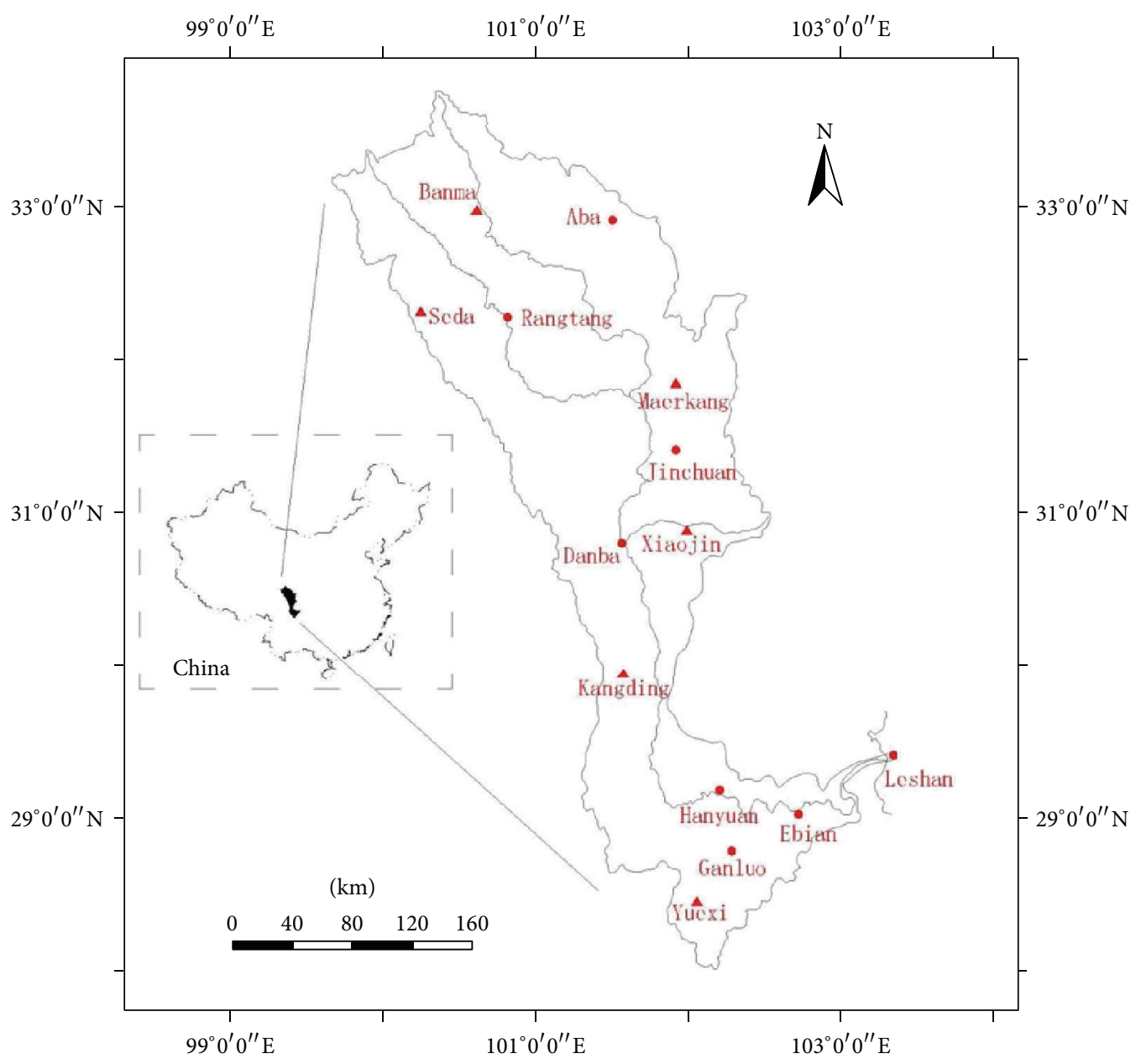

FIGURE 1: Sketch map of the study area.

and precipitation extreme indices are extremely uneven in both space and time in China. Liu et al. [23] analyzed the variation characteristics of five precipitation extreme indices in the Dadu River Basin from 1960 to 2009 and found that the frequency of heavy precipitation has increasing trend.

Up to now, no systematic study has been performed about the trends of temperature and precipitation variation in the Dadu River Basin of China. This study aims to complement the previous researches and the results may have important effects on water resource management and climate risk management. After Introduction, the study area and data are given. Then, the methodology of trend analysis is presented in Section 3. The trends of temperature and precipitation variation are discussed in Section 4. The paper ends with conclusions from the study.

\section{Study Area and Data}

2.1. Description of the Study Area. The Dadu River Basin is located in the southwestern part of China and stretches from latitude $99^{\circ} 42^{\prime} \mathrm{E}$ to $103^{\circ} 75^{\prime} \mathrm{E}$ and from longitude $28^{\circ} 15^{\prime} \mathrm{N}$ to $33^{\circ} 83^{\prime} \mathrm{N}$, with catchment area of $77400 \mathrm{~km}^{2}$ (Figure 1). The river has a total length of $1048 \mathrm{~km}$ and it is the biggest tributary of the Min River which is a tributary of the Yangtze River. After beginning in south of Guoluo Mountain in Qinghai province and flowing south and then east, the Dadu River crosses Leshan before emptying into the Min River. In this basin, the upstream belongs to a plateau climate; the midstream and downstream belong to a subtropical humid climate.

2.2. Data Acquisition and Processing. Fourteen meteorological stations were chosen and they are distributed over the study area as shown in Figure 1. All the stations have daily precipitation data and six of them have daily temperature data. The data was obtained from the China meteorological data sharing service system. And the meteorological station's detailed information is shown in Table 1. Those stations have almost complete records of data and were scanned for discontinuity and outlier. Missing data of one day or two days were filled in by average values of neighboring days. If consecutive days had missing data, the missing values were replaced with long term averages of the same days $[24,25]$.

In this paper, the annual temperature, monthly temperature, mean decade temperature, ten temperature extreme indices, annual precipitation, monthly precipitation, mean 
TABLE 1: Detailed information for meteorological station.

\begin{tabular}{|c|c|c|c|c|c|c|}
\hline Station & ID & Latitude $\left({ }^{\circ} \mathrm{N}\right)$ & Longitude $\left({ }^{\circ} \mathrm{E}\right)$ & Elevation (m) & $\begin{array}{c}\text { Data period } \\
\text { (Temperature) }\end{array}$ & $\begin{array}{c}\text { Data period } \\
\text { (Precipitation) }\end{array}$ \\
\hline Seda & 56152 & 32.27 & 100.35 & 3893.9 & 1960-2012 & 1960-2012 \\
\hline Aba & 56171 & 32.99 & 101.57 & 3275.1 & - & 1955-2008 \\
\hline Banma & 56151 & 32.94 & 100.74 & 3530.0 & 1960-2012 & 1960-2012 \\
\hline Rangtang & 56164 & 32.28 & 100.98 & 3251.0 & - & 1960-2008 \\
\hline Maerkang & 56172 & 31.91 & 102.21 & 2669.8 & 1960-2012 & 1954-2012 \\
\hline Jinchuan & 56168 & 31.54 & 102.07 & 2200.0 & - & 1959-2008 \\
\hline Danba & 56263 & 30.87 & 101.92 & 1321.2 & - & $1956-2008$ \\
\hline Xiaojin & 56178 & 30.99 & 102.38 & 2367 & 1960-2012 & $1952-2008$ \\
\hline Kangding & 56374 & 30.06 & 101.97 & 2615.7 & 1960-2012 & $1952-2012$ \\
\hline Hanyuan & 56376 & 29.35 & 102.68 & 795.9 & - & 1951-2008 \\
\hline Leshan & 56386 & 29.50 & 103.75 & 424.2 & - & 1951-2008 \\
\hline Yuexi & 56475 & 28.62 & 102.55 & 1661.6 & 1965-2012 & 1954-2012 \\
\hline Ebian & 56387 & 29.05 & 103.07 & 761.5 & - & 1959-2008 \\
\hline Ganluo & 56473 & 28.97 & 102.98 & 1170.0 & - & 1959-2008 \\
\hline
\end{tabular}

decade precipitation, and ten precipitation extreme indices have been discussed. The related concepts of temperature and precipitation extreme indices are given in Table 2.

\section{Methodology}

3.1. Mann-Kendall Method. The Mann-Kendall method is expected to be less affected by presence of outliers and missing values because its statistic is based on the sign of differences, not directly on the values of the random variable $[9,26]$. This method has been widely used to assess trends in hydroclimatic data $[5,8,27]$; hence, it was adopted to explore the trends of temperature and precipitation in the Dadu River Basin.

Mann-Kendall trend test is expressed as

$$
K=\sum_{i=1}^{n-1} \sum_{j=i+1}^{n} \operatorname{sgn}\left(x_{i}-x_{j}\right)
$$

where $K$ is a statistic, $x_{i}$ and $x_{j}$ are the sequential data values, $n$ is the length of the time series, and $\operatorname{sgn}()$ is defined as

$$
\operatorname{sgn}\left(x_{i}-x_{j}\right)= \begin{cases}1 & \text { if } x_{i}>x_{j} \\ 0 & \text { if } x_{i}=x_{j} \\ -1 & \text { if } x_{i}<x_{j} .\end{cases}
$$

Since the data is independent and normally distributed, the variance of the $K$ statistic is given by

$$
\operatorname{Var}(K)=\frac{n(n-1)(2 n+5)}{18} .
$$

The values of $K$ and $\operatorname{Var}(K)$ are used to compute the test statistic $Z$ as follows:

$$
Z= \begin{cases}\frac{K-1}{\sqrt{\operatorname{Var}(K)}} & \text { if } K>0 \\ 0 & \text { if } K=0 \\ \frac{K+1}{\sqrt{\operatorname{Var}(K)}} & \text { if } K<0 .\end{cases}
$$

The $Z$ value is used to calculate the statistically significant trend. A positive or negative value of $Z$ represents an upward or downward trend, respectively. The null hypothesis is rejected at the significance level of $\alpha$ if $|Z| \geq Z_{\alpha / 2}$, where $Z_{\alpha / 2}$ is the critical value of the standard normal distribution with a probability exceeding $\alpha / 2$, and it shows that the trend is significant. If $|Z|<Z_{\alpha / 2}$, the null hypothesis is accepted, and the trend is not significant.

A trend is considered to be statistically significant if it is significant at the 0.05 level.

3.2. Sen's Linear Method. To estimate the slope of an existing trend (as change per year), Sen's linear method was used. Sen's linear method can be used in cases where the trend can be assumed to be linear. It is given as

$$
F(t)=q t+b,
$$

where $F(t)$ is the estimate at year $t, b$ is a constant, and $q$ is the slope which denotes the change rate.

\section{Results and Discussion}

4.1. Temperature. Here temperature includes the maximum, mean, and minimum temperature. Trends of above indices are discussed in annual, monthly, decade, and extremes as the following.

Figure 2 shows the spatial distribution of annual average in maximum, mean, and minimum temperature. For 
TABLE 2: Definitions of temperature and precipitation extreme indices used in the present study.

\begin{tabular}{|c|c|c|c|}
\hline Index & Index name & Definitions & Units \\
\hline \multicolumn{4}{|c|}{ Temperature } \\
\hline FD0 & Frost days & Annual count when $\mathrm{TN}$ (daily minimum) $<0^{\circ} \mathrm{C}$ & $\mathrm{d}$ \\
\hline SU25 & Summer days & Annual count when TX (daily maximum) $>25^{\circ} \mathrm{C}$ & $\mathrm{d}$ \\
\hline TXn & Minimum $T_{\max }$ & $\begin{array}{l}\text { Monthly minimum value of daily maximum } \\
\text { temperature }\end{array}$ & ${ }^{\circ} \mathrm{C}$ \\
\hline $\mathrm{TXx}$ & Maximum $T_{\max }$ & $\begin{array}{c}\text { Monthly maximum value of daily maximum } \\
\text { temperature }\end{array}$ & ${ }^{\circ} \mathrm{C}$ \\
\hline $\mathrm{TNn}$ & Minimum $T_{\text {min }}$ & $\begin{array}{l}\text { Monthly minimum value of daily minimum } \\
\text { temperature }\end{array}$ & ${ }^{\circ} \mathrm{C}$ \\
\hline $\mathrm{TNx}$ & Maximum $T_{\min }$ & $\begin{array}{l}\text { Monthly maximum value of daily minimum } \\
\text { temperature }\end{array}$ & ${ }^{\circ} \mathrm{C}$ \\
\hline TX90p & Warm days & Percentage of days when TX $>$ 90th percentile & $\mathrm{d}$ \\
\hline TX10p & Cool days & Percentage of days when TX $<10$ th percentile & $\mathrm{d}$ \\
\hline TN90p & Warm nights & Percentage of days when $\mathrm{TN}>90$ th percentile & $\mathrm{d}$ \\
\hline TN10p & Cool nights & Percentage of days when $\mathrm{TN}<10$ th percentile & $\mathrm{d}$ \\
\hline \multicolumn{4}{|c|}{ Precipitation } \\
\hline $\mathrm{CDD}$ & Consecutive dry days & $\begin{array}{c}\text { Maximum number of consecutive dry days of a } \\
\text { year. The dry day is defined as the day with } \\
\text { precipitation }<1 \mathrm{~mm}\end{array}$ & $\mathrm{~d}$ \\
\hline CWD & Consecutive wet days & $\begin{array}{c}\text { Maximum number of consecutive wet days of a } \\
\text { year. The wet day is defined as the day with } \\
\text { precipitation } \geq 1 \mathrm{~mm}\end{array}$ & $\mathrm{~d}$ \\
\hline $\mathrm{RX} 1$ & $\begin{array}{l}\text { Max 1-day } \\
\text { precipitation amount }\end{array}$ & Maximum 1-day precipitation & $\mathrm{mm}$ \\
\hline RX5 & $\begin{array}{l}\text { Max 5-day } \\
\text { precipitation amount }\end{array}$ & Maximum consecutive 5-day precipitation & $\mathrm{mm}$ \\
\hline R10 & $\begin{array}{l}\text { Heavy precipitation } \\
\text { days }\end{array}$ & $\begin{array}{l}\text { Annual number of days with daily precipitation } \geq \\
\qquad 10 \mathrm{~mm}\end{array}$ & $\mathrm{~d}$ \\
\hline $\mathrm{R} 20$ & $\begin{array}{l}\text { Very heavy } \\
\text { precipitation days }\end{array}$ & $\begin{array}{l}\text { Annual number of days with daily precipitation } \geq \\
\qquad 20 \mathrm{~mm}\end{array}$ & $\mathrm{~d}$ \\
\hline R95p & Very wet days & $\begin{array}{l}\text { Annual total precipitation when daily } \\
\text { precipitation } \geq \text { the } 95 \text { th percentile threshold. The } \\
\text { 95th percentile threshold is calculated based on } \\
\text { the precipitation series of all wet days at each } \\
\text { station }\end{array}$ & $\mathrm{mm}$ \\
\hline R99p & Extremely wet days & $\begin{array}{l}\text { Annual total precipitation when daily } \\
\text { precipitation } \geq \text { the } 99 \text { th percentile threshold. The } \\
\text { 99th percentile threshold is calculated based on } \\
\text { the precipitation series of all wet days at each } \\
\text { station }\end{array}$ & $\mathrm{mm}$ \\
\hline NWD & Number of wet days & $\begin{array}{l}\text { Number of wet days in a year. The wet day is } \\
\text { defined as the day with precipitation } \geq 1 \mathrm{~mm}\end{array}$ & $\mathrm{~d}$ \\
\hline SDII & $\begin{array}{l}\text { Simple daily intensity } \\
\text { index }\end{array}$ & $\begin{array}{l}\text { Annual total precipitation divided by the number } \\
\text { of wet days in the year }\end{array}$ & $\mathrm{mm} / \mathrm{d}$ \\
\hline
\end{tabular}

minimum temperature, the maximum value is obtained in Yuexi $\left(9.2^{\circ} \mathrm{C}\right)$ and minimum value is obtained in Seda $\left(-6.5^{\circ} \mathrm{C}\right)$. Similarly, the maximum value of mean temperature is obtained in Yuexi $\left(13.3^{\circ} \mathrm{C}\right)$ and minimum value is obtained in Seda $\left(0.4^{\circ} \mathrm{C}\right)$. The maximum temperature varied between $9.4^{\circ} \mathrm{C}$ at Seda and $20.1^{\circ} \mathrm{C}$ at Xiaojin. Overall, the temperature in this study area increased from north to south and west to east in space.
4.1.1. Trends in Annual and Monthly Temperature. The trend and regional averages of mean annual and monthly maximum, mean, and minimum temperature were concluded in Table 3. All stations are grouped under four categories of trends (increase/significant increase/decrease/significant decrease) giving the number of stations in each category. It also shows the percentage of stations having increasing and decreasing trends. The regional trends are obtained by 


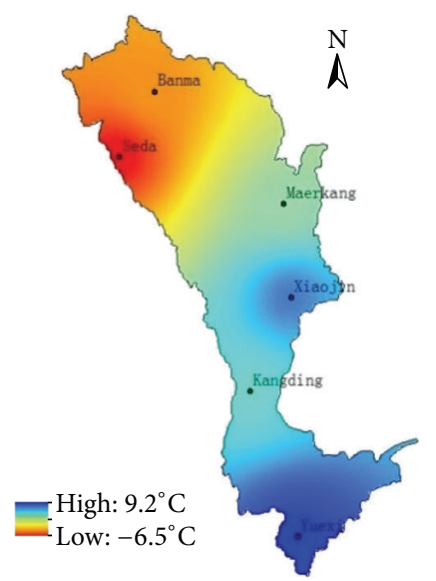

(a)

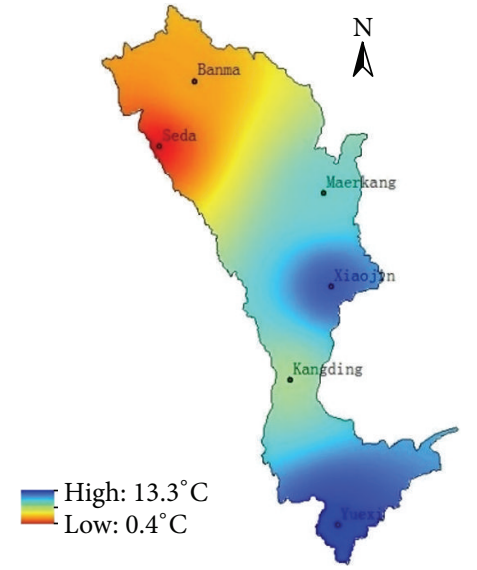

(b)

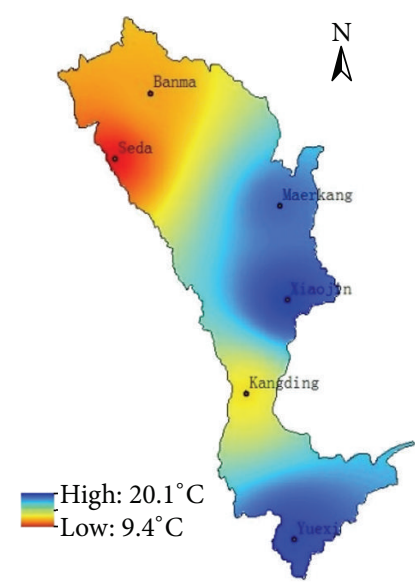

(c)

Figure 2: Spatial distribution of annual average temperature in the study area. (a) Minimum. (b) Mean. (c) Maximum.

averaging the values of indices at all stations for data period. In study area, the annual maximum, mean, and minimum temperature all demonstrated significant increasing trend and the regional averages were $0.17^{\circ} \mathrm{C} /$ decade, $0.15^{\circ} \mathrm{C} /$ decade, and $0.18^{\circ} \mathrm{C} /$ decade, respectively. The results of this study are consistent with some researches about global warming [2$4]$ and some studies about China's warming climate $[12,13]$. For monthly temperature, apart from the downward trend of maximum temperature in March $\left(-0.07^{\circ} \mathrm{C} /\right.$ decade $)$ and April $\left(-0.05^{\circ} \mathrm{C} /\right.$ decade $)$, others exhibited increasing trend. And most of this indices indicated statistically significant increase. However, the minimum temperature's change rates were generally higher than maximum and mean. This finding also agrees with the results of other studies by Easterling et al. [28] and Karl et al. [29].

4.1.2. Trends in Decade Temperature. Figure 3 presents the variation in decade average minimum, mean, and maximum temperature. From 1980s to 1990s, the temperature increases at all stations. Rise in temperature during the period 1990s to 2000s was significant more when compared to other periods. From the period 1960s to 2000s, the maximum, mean, and minimum temperature all showed increase except Yuexi. Overall, since the 1980s, the mean decade temperatures were gradually raising. And in recent twenty years, the temperature was faster growth than before, coinciding with the studies by Zhai et al. [14], Houghton et al. [11], and Chen and Qian [30].

4.1.3. Trends in Extreme Indices of Temperature. Trend and regional averages of ten temperature extreme indices are summarized in Table 4. The FD0 is an index to measure low temperature days. The SU25 is an index to measure high temperature days. A significant decreasing trend was exhibited in FD0 and significant increasing trend was exhibited in SU25, with the regional average of $-2.32 \mathrm{~d} /$ decade and $0.65 \mathrm{~d} /$ decade, respectively. TXn, TXx, TNn, and TNx are a group of indices to depict extreme value of maximum and minimum temperature. It is observed that these four indices all showed significant upward trend. TX90p and Tn90p were the indices of warm days and warm nights. They presented significant increasing trend and the regional average were $2.62 \mathrm{~d} /$ decade and $1.58 \mathrm{~d} /$ decade, respectively. Similarly, Tx10p and Tn10p were the indices of cold days and cold nights. But they presented significant decreasing trend and the regional average was $-1.97 \mathrm{~d} /$ decade and $-3.02 \mathrm{~d} /$ decade, respectively.

The analysis of extreme temperature indices showed a general tendency for significant increase. Whether the decrease of FD0, Tx10p, and Tn10p or the increase of SU25, TXn, TXx, TNn, TNx, TX90p, and Tn90p, they are all powerful evidence of temperature rising.

4.2. Precipitation. It is interpreted from Figure 4 that the annual average precipitation varied from $609.4 \mathrm{~mm}$ at Danba to $1136.3 \mathrm{~mm}$ at Leshan and increased from northwest to southeast in space.

The annual precipitation in this basin revealed upward change from northwest to southeast, and the reasons could be concluded as following: (1) in the northwest area, the characteristic of the obvious dry and wet season, high geographical position, and being far away from water resource caused low precipitation. (2) The southeast area located in the verge of mountain and plain of Sichuan Basin; it led to high precipitation [23].

4.2.1. Trends in Annual and Monthly Precipitation. The trend and regional averages of annual and monthly precipitation at fourteen stations are summarized in Table 5. For annual precipitation, nine stations displayed increasing trend in which two stations showed statistically significant increasing trend, and five stations displayed decreasing trend in which one station showed statistically significant decreasing trend. Namely, the annual precipitation indicated upward trend in this river basin and the regional average was $2.71 \mathrm{~mm} /$ decade. And this study support previous research from Cheng et al. [19]. Analysis of monthly precipitation series revealed significant increase trend in January $(0.16 \mathrm{~mm} /$ decade), March $(1.98 \mathrm{~mm} /$ decade $)$, April $(2.65 \mathrm{~mm} /$ decade $)$, May 


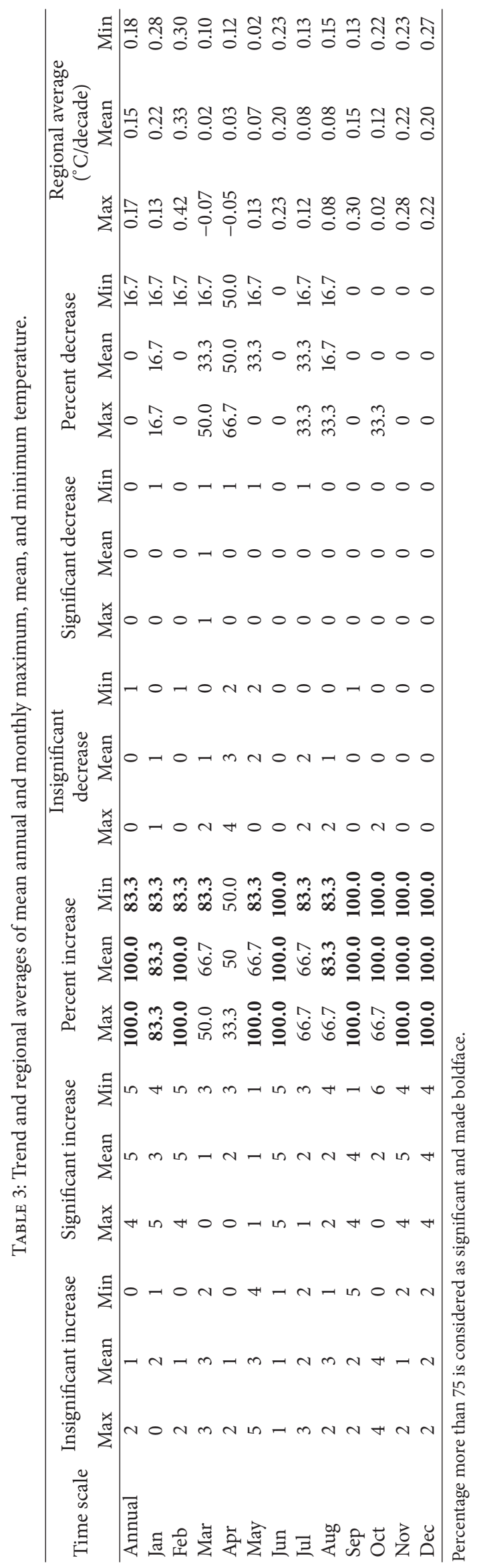




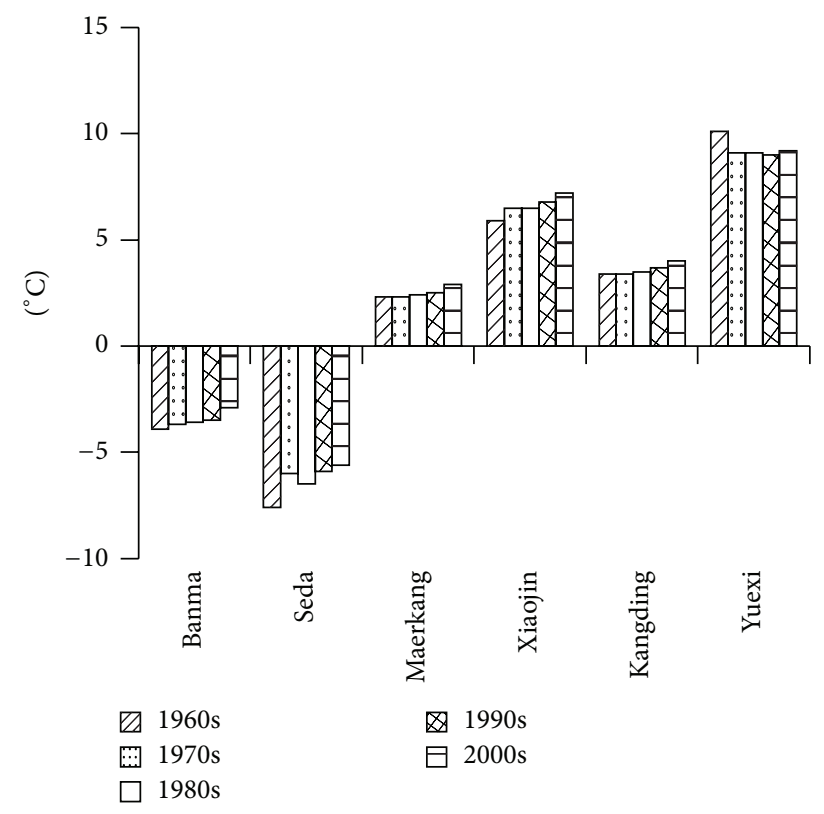

(a)
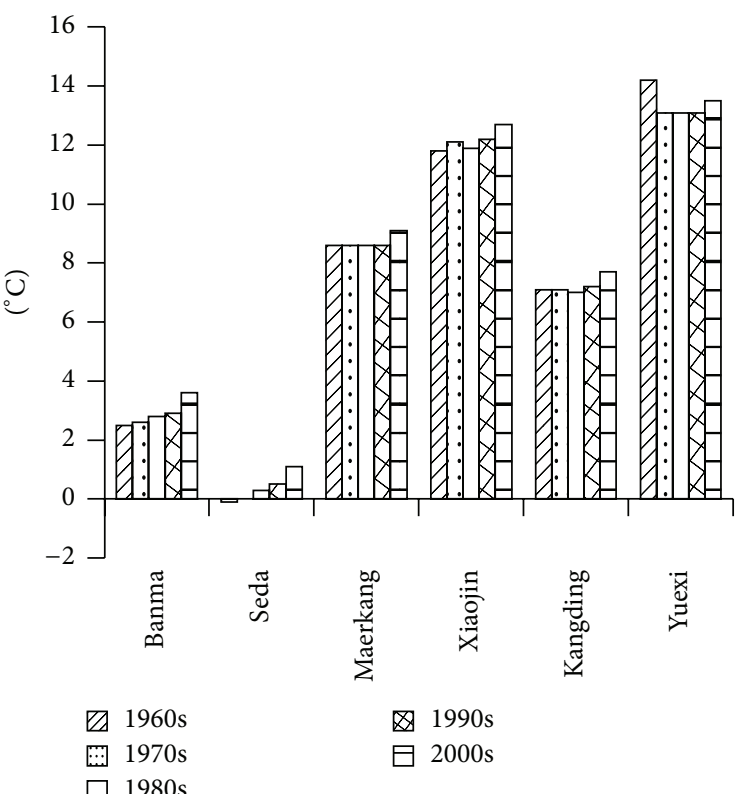

(b)

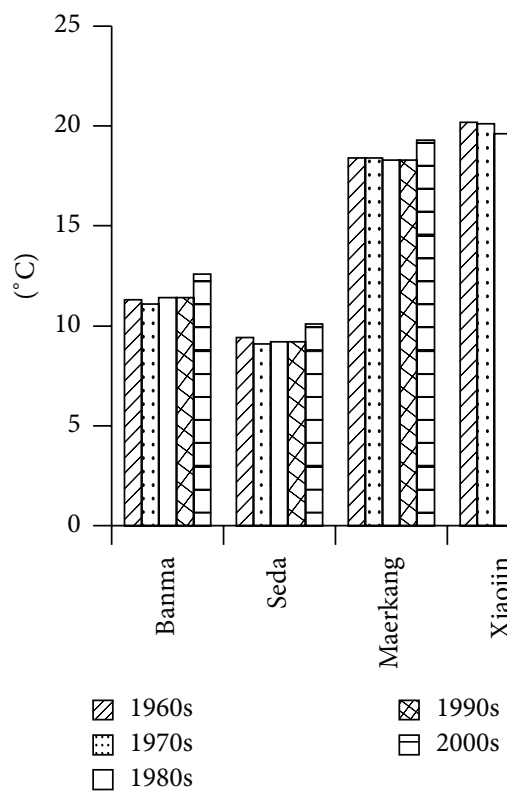

(c)

Figure 3: Variation of decade average temperature in the study area. (a) Minimum. (b) Mean. (c) Maximum.

(1.97 mm/decade), and August $(2.60 \mathrm{~mm} /$ decade $)$, increase in February $(0.24 \mathrm{~mm} /$ decade $)$, June $(1.06 \mathrm{~mm} /$ decade $)$, and October $(0.04 \mathrm{~mm} /$ decade), significant decrease in September $(-4.13 \mathrm{~mm} /$ decade $)$, and decrease in July $(-3.65 \mathrm{~mm} /$ decade), November $(-0.11 \mathrm{~mm} /$ decade $)$, and December $(-0.14 \mathrm{~mm} /$ decade $)$.

4.2.2. Trends in Mean Decade Precipitation. Figure 5 presents the variation of decade average precipitation. As it is shown, the mean precipitations at all the stations in 1980s were more than 1970s and this phenomenon was not obviously in another period. The mean decade precipitation at Danba and Kangding always manifested increase in two consecutive periods. For the period 1960s to 2000s, nine stations revealed increase change and five stations revealed decrease. And the maximum change appeared at Ganluo $(242.1 \mathrm{~mm})$ and the minimum appeared at Banma $(-3.0 \mathrm{~mm})$.

4.2.3. Trends in Extreme Indices of Precipitation. Table 6 presents the trend and regional averages of ten precipitation extreme indices. CDD is an index to measure extreme of consecutive drought. Significant decreasing trend was depicted 
TABLE 4: Trend and regional averages of temperature extreme indices.

\begin{tabular}{|c|c|c|c|c|c|c|c|}
\hline Indices & $\begin{array}{c}\text { Insignificant } \\
\text { increase }\end{array}$ & $\begin{array}{l}\text { Significant } \\
\text { increase }\end{array}$ & Percent increase & $\begin{array}{c}\text { Insignificant } \\
\text { decrease }\end{array}$ & $\begin{array}{c}\text { Significant } \\
\text { decrease }\end{array}$ & $\begin{array}{l}\text { Percent } \\
\text { decrease }\end{array}$ & $\begin{array}{c}\text { Regional average } \\
\left({ }^{\circ} \mathrm{C} / \text { decade }\right)\end{array}$ \\
\hline FD0 & 0 & 1 & 16.7 & 0 & 5 & 83.3 & -2.32 \\
\hline SU25 & 3 & 2 & 83.3 & 1 & 0 & 16.7 & 0.63 \\
\hline TXn & 4 & 2 & 100 & 0 & 0 & 0 & 0.20 \\
\hline TXx & 1 & 5 & 100 & 0 & 0 & 0 & 0.22 \\
\hline $\mathrm{TNn}$ & 1 & 4 & 83.3 & 1 & 0 & 16.7 & 0.33 \\
\hline $\mathrm{TNx}$ & 0 & 5 & 83.3 & 1 & 0 & 16.7 & 0.15 \\
\hline TX90p & 1 & 5 & 100 & 0 & 0 & 0 & 2.62 \\
\hline TX10p & 1 & 0 & 16.7 & 1 & 4 & 83.3 & -1.97 \\
\hline TN90p & 2 & 3 & 83.3 & 0 & 1 & 16.7 & 1.58 \\
\hline TN10p & 1 & 0 & 16.7 & 0 & 5 & 83.3 & -3.02 \\
\hline
\end{tabular}

Percentage more than 75 is considered as significant and made boldface.

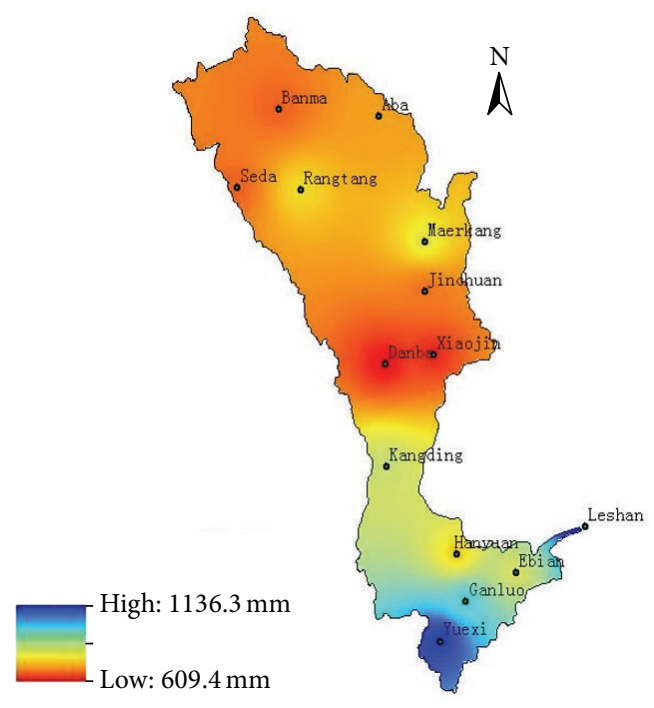

FIGURE 4: Spatial distribution of annual average precipitation in the study area.

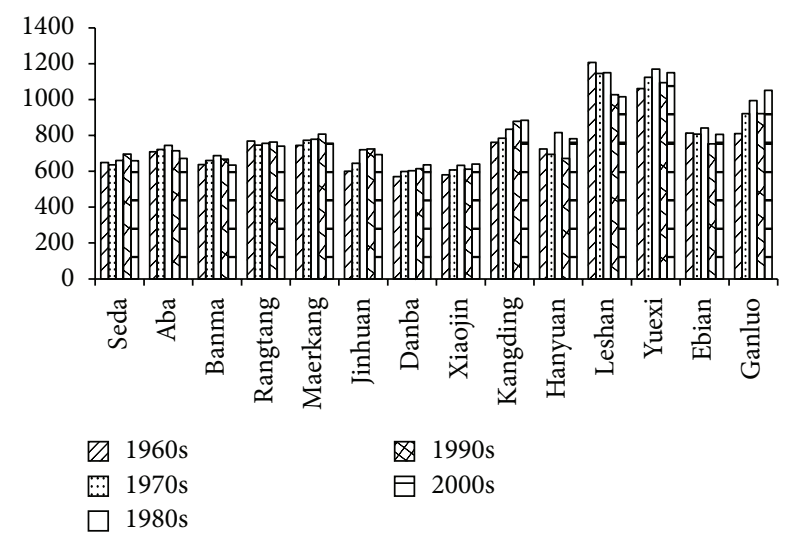

FIGURE 5: Variation of decade average precipitation in the study area. in study area, and the regional average was $-0.59 \mathrm{~d} /$ decade. CWD is an index to measure extreme of consecutive precipitation. Corresponding with the CDD, CWD showed decreasing trend and the regional average was $-0.06 \mathrm{~d} / \mathrm{decade}$. The maximum event intensity indices, namely, RX1d and RX5d, showed no obvious trend and downward trend in this region with the regional average of $0.05 \mathrm{~mm} /$ decade and $-0.88 \mathrm{~mm} /$ decade, respectively. Similarly, the indicators of heavy precipitation, namely, R10 and R20, displayed increasing trend with the regional average of $0.06 \mathrm{~d} /$ decade and $0.07 \mathrm{~d} / \mathrm{decade}$, respectively. Other measures of extreme precipitation are the percentage of total precipitation due to events above the 95th and 99th percentile (R95p and R99p). In this river basin, R95p indicated an increasing trend with the regional average of $2.89 \mathrm{~mm} /$ decade. R99p indicated an increasing trend but the regional average was $-0.86 \mathrm{~mm} /$ decade. This discrepant phenomenon could be explained by the different theory foundation of these two trend test analysis methods and this inconsistent variance might be reasonable on a small scale. The NWD is the number of wet days. And in this area, NWD exhibited increasing trend and the regional average is $0.19 \mathrm{~d} /$ decade. The trend of SDII depends on the combined effect of NWD and annual total wet day precipitation trend. A significant upward trend is displayed in this region with the average of $0.04 \mathrm{~mm} / \mathrm{decade}$.

Above all, except the CDD and SDII, the trends of precipitation indices are not significant. However, the significant decrease of the CDD and the increase of SDII illustrate that the precipitation has increased to some extent.

\section{Conclusions}

This study evaluated the variation trends of temperature and precipitation in the Dadu River Basin of China based on observed records from fourteen meteorological stations. And the annual temperature, monthly temperature, mean decade temperature, ten temperature extreme indices, annual precipitation, monthly precipitation, mean decade precipitation, 
TABLE 5: Trend and regional averages of annual and monthly precipitation.

\begin{tabular}{|c|c|c|c|c|c|c|c|}
\hline Time scale & $\begin{array}{c}\text { Insignificant } \\
\text { increase }\end{array}$ & $\begin{array}{c}\text { Significant } \\
\text { increase }\end{array}$ & Percent increase & $\begin{array}{c}\text { Insignificant } \\
\text { decrease }\end{array}$ & $\begin{array}{c}\text { Significant } \\
\text { decrease }\end{array}$ & $\begin{array}{c}\text { Percent } \\
\text { decrease }\end{array}$ & $\begin{array}{c}\text { Regional averages } \\
\text { (mm/decade) }\end{array}$ \\
\hline Annual & 7 & 2 & 64.3 & 4 & 1 & 35.7 & 2.71 \\
\hline Jan & 12 & 0 & 85.7 & 2 & 0 & 14.3 & 0.16 \\
\hline Feb & 7 & 1 & 57.1 & 6 & 0 & 42.9 & 0.24 \\
\hline Mar & 8 & 6 & 100 & 0 & 0 & 0 & 1.98 \\
\hline Apr & 6 & 6 & 85.7 & 2 & 0 & 14.3 & 2.65 \\
\hline May & 11 & 0 & 78.6 & 3 & 0 & 21.4 & 1.97 \\
\hline Jun & 6 & 1 & 53.8 & 6 & 0 & 46.2 & 1.06 \\
\hline Jul & 5 & 0 & 38.5 & 5 & 3 & 61.5 & -3.65 \\
\hline Aug & 10 & 1 & 78.6 & 3 & 0 & 21.4 & 2.60 \\
\hline Sep & 1 & 0 & 7.7 & 8 & 4 & 92.3 & -4.13 \\
\hline Oct & 7 & 1 & 61.5 & 4 & 1 & 38.5 & 0.04 \\
\hline Nov & 6 & 0 & 42.9 & 8 & 0 & 57.1 & -0.11 \\
\hline Dec & 5 & 0 & 38.5 & 7 & 1 & 61.5 & -0.14 \\
\hline
\end{tabular}

Percentage more than 75 is considered as significant and made boldface.

TABLE 6: Trend and regional averages of precipitation extreme indices.

\begin{tabular}{|c|c|c|c|c|c|c|c|}
\hline Indices & $\begin{array}{l}\text { Insignificant } \\
\text { increase }\end{array}$ & $\begin{array}{l}\text { Significant } \\
\text { increase }\end{array}$ & Percent increase & $\begin{array}{c}\text { Insignificant } \\
\text { decrease }\end{array}$ & $\begin{array}{l}\text { Significant } \\
\text { decrease }\end{array}$ & $\begin{array}{c}\text { Percent } \\
\text { decrease }\end{array}$ & $\begin{array}{l}\text { Regional average } \\
\text { (unit/decade) }\end{array}$ \\
\hline CDD & 3 & 0 & 23.1 & 10 & 0 & 76.9 & -0.59 \\
\hline CWD & 3 & 1 & 28.6 & 9 & 1 & 71.4 & -0.06 \\
\hline $\mathrm{RX1}$ & 7 & 0 & 50.0 & 7 & 0 & 50.0 & 0.05 \\
\hline RX5 & 4 & 1 & 38.5 & 4 & 4 & 61.5 & -0.88 \\
\hline R10 & 7 & 1 & 57.1 & 5 & 1 & 42.9 & 0.06 \\
\hline R20 & 6 & 2 & 61.5 & 3 & 2 & 38.5 & 0.07 \\
\hline R95p & 7 & 1 & 66.7 & 2 & 2 & 33.3 & 2.89 \\
\hline R99p & 7 & 0 & 53.8 & 4 & 2 & 46.2 & -0.86 \\
\hline NWD & 5 & 3 & 57.1 & 4 & 2 & 42.8 & 0.19 \\
\hline SDII & 7 & 4 & 78.6 & 3 & 0 & 21.4 & 0.04 \\
\hline
\end{tabular}

Percentage more than 75 is considered as significant and made boldface.

and ten precipitation extreme indices have been analyzed. Meanwhile, the magnitude of trends was estimated using Sen's Linear method while its statistical significance was evaluated using Mann-Kendall's test. The main findings and conclusions of the study are the following:

(1) The temperature in Dadu River Basin increased from north to south and west to east in space. In temporal scale, the annual maximum, mean, and minimum temperature all displayed significant increasing trend with a linear rising rate of $0.17^{\circ} \mathrm{C} /$ decade, $0.15^{\circ} \mathrm{C} /$ decade, and $0.18^{\circ} \mathrm{C} /$ decade, respectively. Apart from April, the monthly maximum, mean, and minimum temperature all displayed upward trend. Moreover, since the 1980s, the mean decade temperatures were gradually raising. Especially in recent twenty years, the temperature had faster growth than before. Besides, the minimum temperature's rising rates were generally higher than maximum and mean. The extreme temperature indices showed a general tendency for significant increase. The FD0 presented significant downward trend and the SU25 presented significant upward. Significant increase was noticed in theTX90p and Tn90p, with corresponding significant decrease in theTx10p and Tn10p. For TXn, $\mathrm{TXx}, \mathrm{TNn}$, and TNx, they all indicated significant increasing trend.

(2) The annual precipitation in this basin increased from northwest to southeast in space. And the annual precipitation displayed upward trend with an increasing rate of $2.71 \mathrm{~mm} /$ decade in time. For monthly precipitation, significant increase was manifested in January, March, April, May, and August and significant decrease was revealed in September. All the stations' mean precipitation in 1980s was more than 1970s and this phenomenon was not obvious in other period. The maximum change in mean decade precipitation from 1960s to 2000s appeared at Ganluo $(242.1 \mathrm{~mm})$ and the minimum change appeared at 
Banma $(-3.0 \mathrm{~mm})$. For extreme precipitation indices, the CDD exhibited a significant decreasing trend and the SDII exhibited significant increasing trend. Apart from above two indices, others' tendency was not significant.

This study contributes valuable information on trends of temperature and precipitation in Dadu River Basin which has practical meanings for an effective management of water resources and climate risk. Furthermore, this paper provides a foundation for further study of hydrological situation in this river basin.

\section{Appendix}

See Table 3.

\section{Competing Interests}

The authors declare that they have no competing interests.

\section{Acknowledgments}

This study is financially supported by the National Science Foundation of China (no. 51179110) and the National Key Basic Research Program of China (no. 2013CB036401).

\section{References}

[1] T. J. Crowley, "Causes of climate change over the past 1000 years," Science, vol. 289, no. 5477, pp. 270-277, 2000.

[2] D. E. Parker, E. B. Horton, and L. V. Alexander, "Global and regional climate in 1999," Weather, vol. 55, no. 6, pp. 188-199, 2000.

[3] J. Hansen, M. Sato, R. Ruedy, K. Lo, D. W. Lea, and M. Medina-Elizade, "Global temperature change," Proceedings of the National Academy of Sciences of the United States of America, vol. 103, no. 39, pp. 14288-14293, 2006.

[4] IPCC (International Panel on Climate Change), Climate Change: Fourth Assessment Report of the Intergovernmental Panel on Climate Change, Cambridge University Press, Cambridge, UK, 2007.

[5] D. L. Li, W. S. Wang, S. X. Hu, and Y. Q. Li, "Characteristics of annual runoff variation in major rivers of China," Hydrological Processes, vol. 26, no. 19, pp. 2866-2877, 2012.

[6] M. Al-Mukhtar, V. Dunger, and B. Merkel, "Assessing the impacts of climate change on hydrology of the upper reach of the spree river: Germany," Water Resources Management, vol. 28, no. 10, pp. 2731-2749, 2014.

[7] K. Rasouli, J. W. Pomeroy, J. R. Janowicz, S. K. Carey, and T. J. Williams, "Hydrological sensitivity of a northern mountain basin to climate change," Hydrological Processes, vol. 28, no. 14, pp. 4191-4208, 2014.

[8] J. Tang, X.-A. Yin, P. Yang, and Z. Yang, "Assessment of contributions of climatic variation and human activities to streamflow changes in the Lancang River, China," Water Resources Management, vol. 28, no. 10, pp. 2953-2966, 2014.

[9] D. Sharma and M. S. Babel, "Trends in extreme rainfall and temperature indices in the western Thailand," International Journal of Climatology, vol. 34, no. 7, pp. 2393-2407, 2014.
[10] P. Y. Groisman, R. W. Knight, D. R. Easterling, T. R. Karl, G. C. Hegerl, and V. N. Razuvaev, "Trends in intense precipitation in the climate record," Journal of Climate, vol. 18, no. 9, pp. 13261350, 2005.

[11] J. T. Houghton, Y. H. Ding, D. Griggs et al., IPCC, Climate Change 2001: The Scientific Basis, Summary of Working Group I Report, Cambridge University Press, Cambridge, UK, 2001.

[12] Y. H. Ding, G. Y. Ren, G. Y. Shi et al., "China's National Assessment Report on Climate Change (I): Climate change in China and the future trend," Advances in Climate Change Research, vol. 2, pp. 3-8, 2006.

[13] C. H. Han, Z. X. Hao, and J. Y. Zhen, "Regionalization of temperature changes in China and characteristics of temperature in different regions during 1951-2010," Progress in Geography, vol. 32, pp. 887-896, 2013 (Chinese).

[14] P. M. Zhai, A. Sun, F. M. Ren, X. Liu, B. Gao, and Q. Zhang, "Changes of climate extremes in China," Climatic Change, vol. 42, no. 1, pp. 203-218, 1999.

[15] B. H. Liu, M. Xu, M. Henderson, and Y. Qi, "Observed trends of precipitation amount, frequency, and intensity in China, 19602000," Journal of Geophysical Research D: Atmospheres, vol. 110, no. 8, Article ID D08103, pp. 1-10, 2005.

[16] Q. Zhang, C.-Y. Xu, and Z. Zhang, "Observed changes of drought/wetness episodes in the Pearl River basin, China, using the standardized precipitation index and aridity index," Theoretical and Applied Climatology, vol. 98, no. 1-2, pp. 89-99, 2009.

[17] D. Yang, C. Li, H. Hu et al., "Analysis of water resources variability in the Yellow River of China during the last half century using historical data," Water Resources Research, vol. 40, no. 6, Article ID W06502, 2004.

[18] Q. Zhang, T. Jiang, M. Gemmer, and S. Becker, "Precipitation, temperature and runoff analysis from 1950 to 2002 in the Yangtze basin, China," Hydrological Sciences Journal, vol. 50, no. 1, pp. 65-80, 2005.

[19] K. Cheng, D. S. Zhou, M. Li, and W. Zhan, "Characteristic analysis of precipitation and runoff in Dadu river in last 51 years," Water Resources and Power, vol. 31, pp. 5-8, 2013 (Chinese).

[20] CCSP, "Weather and climate extremes in a changing. regions of focus: North America, Hawaii, Caribbean, and U.S. Pacific Islands," in Report by the U.S. Climate Change Science Program and the Subcommittee on Global Change Research, T. R. Karl, G. A. Meehl, C. D. Miller, S. J. Hassol, A. M. Waple, and W. L. Murray, Eds., p. 164, Department of Commerce, NOAA's National Climatic Data Center, Washington, DC, USA, 2008.

[21] Y. Q. Wang and L. Zhou, "Observed trends in extreme precipitation events in China during 1961-2001 and the associated changes in large-scale circulation," Geophysical Research Letters, vol. 32, no. 9, Article ID L09707, pp. 1-4, 2005.

[22] Q. Zhang, J. L. Li, V. P. Singh, and M. Xiao, "Spatio-temporal relations between temperature and precipitation regimes: implications for temperature-induced changes in the hydrological cycle," Global and Planetary Change, vol. 111, pp. 57-76, 2013.

[23] J. Liu, Z. F. Ma, S. Q. Yang, X. B. Yang, and X. L. Li, "Climatic characteristics of extreme precipitation events in the Dadu River Basin during 1961-2010," Resources and Environment in the Yangtze Basin, vol. 24, no. 12, pp. 2166-2176, 2015 (Chinese).

[24] Q. Zhang, C.-Y. Xu, M. Gemmer, Y. D. Chen, and C. Liu, "Changing properties of precipitation concentration in the Pearl River basin, China," Stochastic Environmental Research and Risk Assessment, vol. 23, no. 3, pp. 377-385, 2009. 
[25] Q. Zhang, V. P. Singh, J. Li, and X. Chen, "Analysis of the periods of maximum consecutive wet days in China," Journal of Geophysical Research Atmospheres, vol. 116, no. 23, pp. 20532056, 2011.

[26] M. A. Degefu and W. Bewket, "Variability and trends in rainfall amount and extreme event indices in the Omo-Ghibe River Basin, Ethiopia," Regional Environmental Change, vol. 14, no. 2, pp. 799-810, 2014.

[27] S. Yue and C. Y. Wang, "The Mann-Kendall test modified by effective sample size to detect trend in serially correlated hydrological series," Water Resources Management, vol. 18, no. 3, pp. 201-218, 2004.

[28] D. R. Easterling, B. Horton, P. D. Jones et al., "Maximum and minimum temperature trends for the globe," Science, vol. 277, no. 5324, pp. 364-367, 1997.

[29] T. R. Karl, N. Nicholls, and A. Ghazi, "Clivar/GCOS/WMO workshop on indices and indicators for climate extremes workshop summary," Climatic Change, vol. 42, no. 1, pp. 3-7, 1999.

[30] J. Q. Chen and L. L. Qian, "The variations of air temperature in Sichuan Basin during 1961-2000," Journal of Changjiang Engineering Vocational College, vol. 30, pp. 12-15, 2013 (Chinese). 

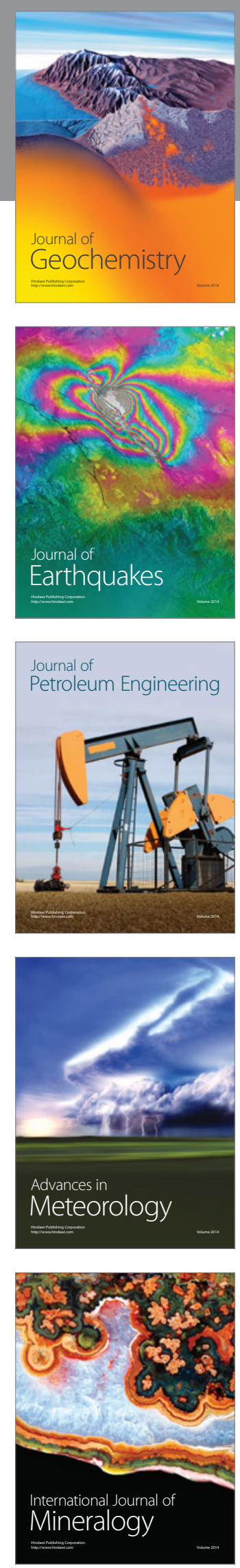
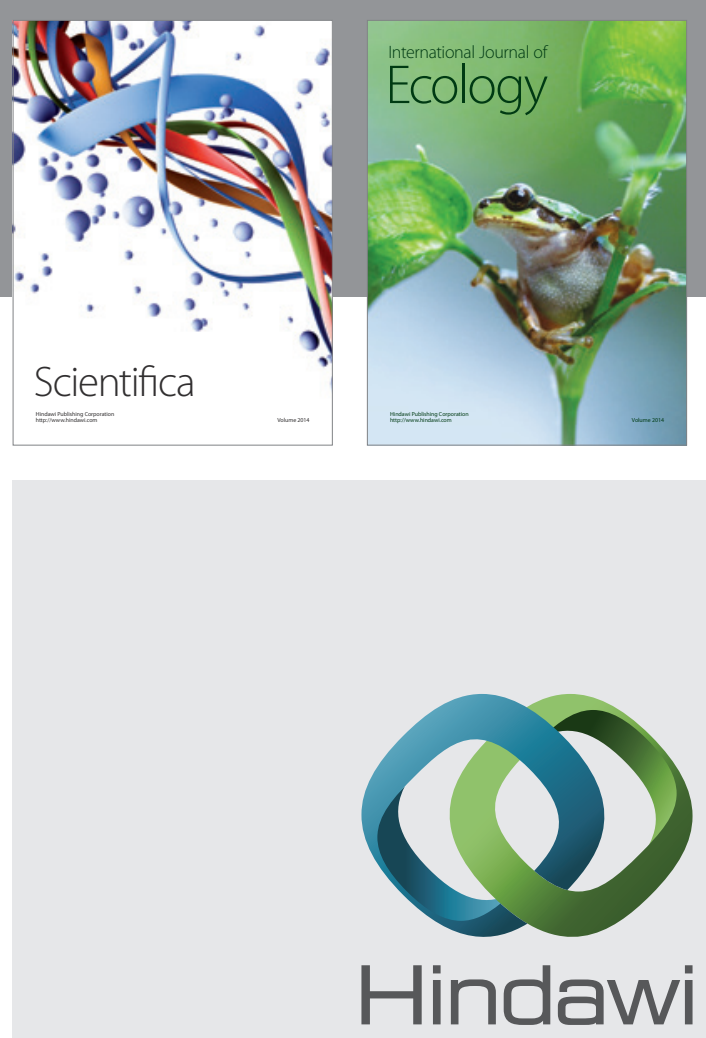

Submit your manuscripts at

http://www.hindawi.com
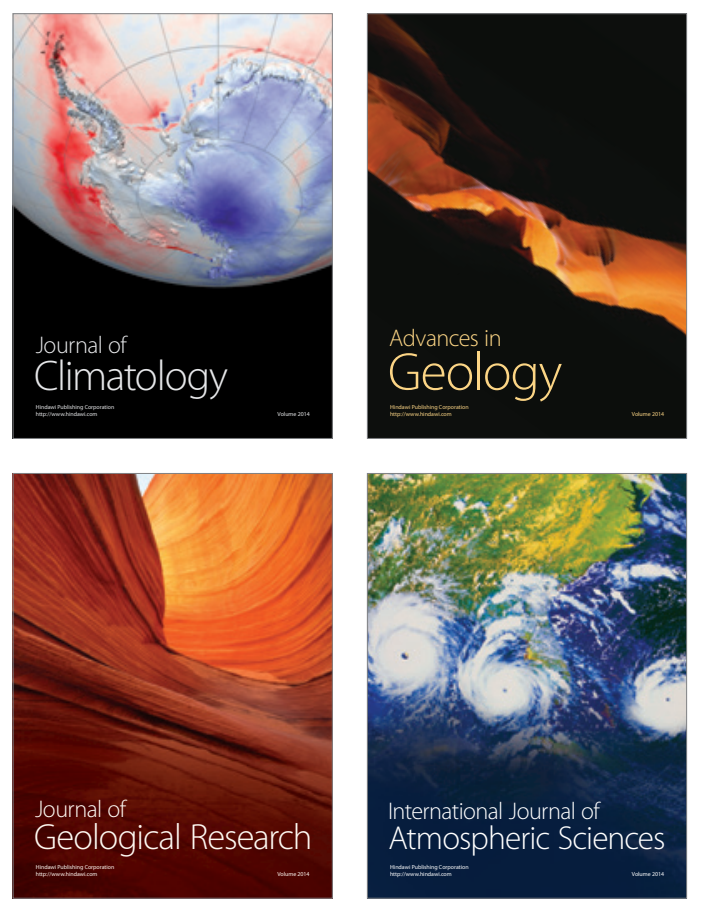

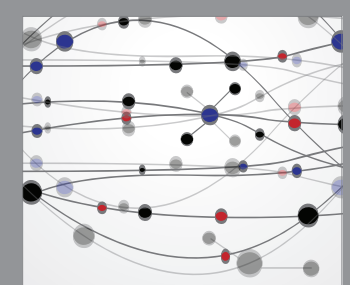

The Scientific

\section{World Journal}
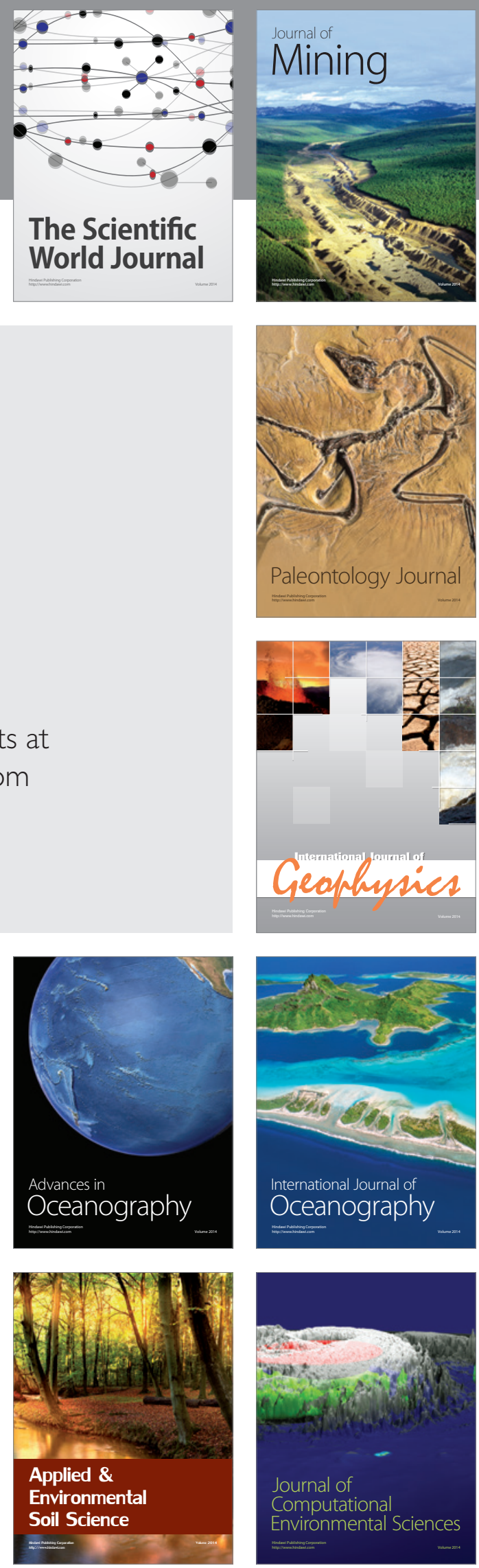